\title{
Language Models and the Teaching of English Language to Secondary School Students in Cameroon
}

\author{
Njwe Amah Eyovi Ntongieh ${ }^{1, *}$ \\ ${ }^{1}$ Department of English Modern Letters, Higher Teacher Training College, University of Bamenda, Bamenda, \\ Cameroon \\ *Correspondence: Department of English Modern Letters, Higher Teacher Training College, University of Bamenda, \\ Bamenda, Cameroon. E-mail: eyovinjwe@yahoo.com
}

Received: February 17, 2016

Accepted: March 29, 2016 Online Published: April 18, 2016

doi:10.5430/wje.v6n2p50

URL: http://dx.doi.org/10.5430/wje.v6n2p50

\begin{abstract}
This paper investigates Language models with an emphasis on an appraisal of the Competence Based Language Teaching Model (CBLT) employed in the teaching and learning of English language in Cameroon. Research endeavours at various levels combined with cumulative deficiencies experienced over the years have propelled educational policy makers to carry out various changes in the models emphasised in the teaching of language. Such changes have been undertaken in view of improving proficiency in communication as well as performance in various examinations. This is especially apt during this era when there is a dire need and great aspirations towards evolving Cameroon into an emergent nation by 2035. Findings derived from different educational stakeholders, including pedagogic inspectors, as well as school administrators, teachers and students from secondary schools located in the North West and South West regions of the Republic of Cameroon have been used in this investigation. Questionnaires, observations and interviews were employed to elucidate the information analysed in this study.
\end{abstract}

Keywords: language; teaching; models; competence; communication; proficiency

\section{Introduction}

It is common knowledge that the performance of Anglophone Secondary school students in English Language both in everyday communication and examinations have experienced decline over the years. The climax was the very poor performances registered in the G.C.E. O/L English language examination of 2014 where there was a meagre 13\% success for a subject which constitutes a basic university entry requirement for many Anglo-Saxon based Universities for this group of students. As if this was not bad enough, the newly introduced Advanced level English language paper of 2015 G.C.E. examination produced an even worse result with a maiden attempt performance of $8 \%$ pass in the subject. The intriguing situation is the fact that, English language is the medium through which all the other school certificate subjects are taught and learnt. It is assumed that a better mastery of English language will greatly enhance comprehension and performances in the other subjects and permit these users to function well in this country where English and French are official languages superposed on about 273 indigenous languages.

Furthermore, the deplorable situation in the performance of English language provokes thoughts and investigations into a number of factors all geared towards possibilities of eventually redressing the situation. This is to be done so that there will be a fostering of the communication skills of users for better performance and usage and permitting them to function more appropriately in the globalized world where English language is a leading medium of communication. It is from this back drop that this paper sets out to investigate the various models employed in the teaching of English language with a focus on an appraisal of The Competence Based Language Teaching (CBLT) model recently introduced in 2012 in Cameroon. In essence, there is the need to describe and highlight the contributions of the various models in the teaching of English, the problems encountered by each model and steps which were undertaken to redress such problems and of greater relevance, there is the need to present an appraisal of the newly introduced CBLT model to see whether it is actually functioning to address the language needs of our students. 


\section{Description of the Various Models}

Various models or Approaches have been employed and emphasized in the business of teaching languages in different parts of the world at different times and various degrees or levels of successes have been registered according to the needs emphasized. Some of such models include the Grammar Translation, the Direct, the Communicative, the Audio-Lingual, the Bilingual, the Michael West or New Model, and the Competence Based Approach or model. In this study, the focus will be on four models which have been very prominent in the Cameroonian scenario in the teaching of English language. These include the Grammar-Translation, the Direct, the Communicative and the Competence Based Language Teaching Models.

\subsection{Grammar-Translation Model}

The classical or Grammar-Translation model represents the tradition of language teaching adopted in Western societies and developed over centuries of teaching not only the classical languages such as Latin and Greek but also foreign languages. It remained popular in modern language pedagogy, even after the introduction of newer methods. The procedure in this method is such that the learner's first language for example French or German is used as the means of translating to the target language (say English). In this approach, the teacher's role is central as he or she is looked upon as a model to be imitated. The model emphasises the teaching of grammar and vocabulary. This is done through the teaching of prescriptive grammar in a deductive manner through the presentation of grammatical rules and vocabulary in the form of list of words presented out of context and grouped thematically for students to memorise.

The meaning of words are learnt through translation into the mother tongue or first language. There is little active use of the target language as classes are in the students' mother tongue. There is also the study of the form and inflection of words. Reading of difficult text is begun early in the course of study. Little attention is paid to the content of texts, which are treated as exercises in grammatical analysis. The only drills most often used, are exercises in translating disconnected sentences from the target language into the mother tongue and vice versa. There is little or no attention provided for the development of pronunciation skills.

According to Kumaravadivelu's (1993) classification, this approach falls under language centred methods because its focus is principally with linguistic forms. This approach which could also be termed a content based approach seeks to provide opportunities for learners to practice preselected, pre-sequenced linguistic structures through form focused exercises in class, assuming that a preoccupation with form will ultimately lead to the mastery of the target language and that the learners can draw from this formal repertoire whenever they wish to communicate in the target language outside the class. From this perspective, language development is more intentional than incidental. In other words, learners are expected to pay continual and conscious attention to linguistic features through systematic planning and sustained practice in order to learn and to use them. Grammar Translation approach give priority to grammatical Competence as the basis of Language proficiency. Grammar rules could be learnt through a methodology that makes much use of repetitive practice and drilling. Great attention is paid to accurate mastery of grammar from the beginning phases of language learning. The methodology employed is structural which has to do with presentation, practice and production. The target grammar structure is presented often by means of a short text. The students practise using the new structure in a controlled context through drills or substitution exercises. In production, the students produce using the new structure in different context, often using content provided by the teacher.

\subsubsection{The Grammar-Translation Model in Cameroon}

This model was advocated and practised in the teaching of English language to Anglophone Secondary School students (our focus in this study) by language pedagogues till the late seventies. In investigating this aspect of this study, a total of four regional pedagogic inspectors, two each from the North West and South West regions and one National inspector for English language alongside twenty teachers from both regions in the business of English language teaching for more than twenty five years as well as ten retired English teachers interviewed for this research reported as follows:

1. They explained that, the students taught through the Grammar Translation Model came from diverse linguistic background whereby the different Cameroonian Languages constituted their various mother tongues and some also had a good mastery of the lingua franca pidgin English spoken in Cameroon. They all had carried out primary school studies in English. At the secondary school level, teaching and learning of English language through the Grammar-Translation Model emphasized the aspect of a good mastery of the grammar rules of English to the extent of rote memorization of such rules; there was vocabulary study as well as the study of complex literary texts. There were no translation from one language to another. 
However, the aspect of translation involved the teaching of English to Francophone students whereby this required the movement from French to English and vice versa.

2. The Grammar-Translation Model enforced the systematic study of grammatical rules which helped in fostering students' ability of reading comprehension and producing grammatically correct sentences. They reported that the skills were developed more in writing than in speaking. They also observed that the knowledge of grammatical rules aided in making communication intelligible.

They further pointed out that, there was much emphasises on the use of literary texts and acknowledged the fact that these texts provided the situation in which reading and writing abilities were developed. They observed with great dismay that, this model's major limitation was the emphasis on the learning of grammatical rules which were not applied in real life communication situations.

In other words, reading and writing skills were enhanced to the detriment of listening and speaking skills. The texts used were mostly taken from literary works, which most often did not meet the practical everyday needs of the learners. The environment outside the classroom did not employ the use of English language so there was no place to practice the rule of grammar to increase proficiency in the language. This model was eventually abandoned for a model which emphasized communication in real life situations.

\subsection{The Direct Method}

The fact that the Grammar-Translation approach did not emphasize oral communication and the application of English language in real life situations it was discarded as an approach for teaching English. The next model embraced for the teaching of English was the Direct Method or Approach. This approach has many names. It is called the 'reform' method, the 'natural' method, the 'psychological' method, the 'phonetic' method, and 'anti-grammatical' method. It was first established in France and Germany around 1900. The major assumptions were in opposition to the grammar-translation and had distinct grammatical bias. It is a logical extension of the Natural method an offshoot of the Behaviourist school of psychology. It insists on the fact that the key to all language learning lies in association. It stresses the need for direct association between experience and expression in the foreign language.

The aim is to enable the learner to think in the foreign language and to cultivate an unerring language sense. It recognizes that language sense has its roots in the spoken language and lays stress on the oral approach. Meanings of words for example should be taught by direct association through giving synonyms, definitions, explanations or by inference to the context. There should be no recourse to translations for indirect learning.

Another significant assumption of this model include the fact that adult L2 learners could learn a second language in essentially the same manner as children do. The teacher here, is expected to create a natural learning environment within the classroom and instead of explicit grammar instruction, the major emphasis is on communication through question-and-answer dialogues. The teacher was the expert and the students had to imitate him. This presented a great weakness in the Cameroonian situation because of the lack of dearth of the expert teachers.

The oral practice was limited to the classroom setting such that outside, there were no real avenues to continue with the practice. Moreover, a total abandonment of the grammar rules in an environment where English is not the indigenous language started the deficiencies which have cumulated over the years. As opined by Verghese (1989) another limitation of this model, arises from its neglect of the language Skills like writing and reading because of overemphasis on oral work.

The next model which immediately followed the Direct Method in the Cameroonian language teaching scene was the Communicative language Teaching Model. Like the Direct Method, it also emphasized oral skills, but at the same time highlighted certain communication functions.

\subsection{The Communication Language Teaching Model}

This model as observed by Essossomo (2013) advocated the teaching of language for communicative purposes and not only for the sake of passing examinations. There was the need to learn enough realistic whole language introducing innovative classroom activities like games, role play and scenarios aimed at sustaining learner motivation (Kumaravadivlu, 2006). The model has evolved to incorporate basic grammatical principles in performing communicative functions.

This approach seeks to provide opportunities for learners to practice preselected, pre sequenced linguistic structures and communicative notions/functions through meaning-focused activities, assuming that a preoccupation with form 
and function will ultimately lead to target language mastery and that the learners can make use of both formal and functional repertoire to fulfil their communicative needs outside the class. (Kumaravadivelu, 2008).

Hymes, (1972) cited in Essossomo (2013) mentions some criteria by which communicative competence can be evaluated. These include the formal possibility connected to grammaticality, appropriateness linked to sociocultural acceptability, and the actual performance.

Here, classroom activities seek to develop students' communicative competence through linking grammatical development to the ability to communicate. Therefore, grammar is not taught in isolation but often arises out of a communicative task, thus creating a need for specific items of grammar. Students might carry out a task and then reflect on some of the linguistic characteristics of their performance. They create the need for communication, interaction, and negotiation of meaning through the use of activities such as problem solving, information sharing, and role play. They provide opportunities for both inductive as well as deductive learning of grammar. They make use of content that connects to students' lives and interests. They allow students to personalize learning by applying what they have learned to their own lives. Classroom materials typically make use of authentic texts to create interest and to provide valid models of language.

The advantages of this model include the fact that;

The learner is at the centre and takes on more responsibilities. Students have the opportunity to construct knowledge themselves and this gives meaning to learning. Here, the learner has the responsibility not just to learn how to communicate but equally to learn the grammar of the language in order for communication to be more intelligible.

It involves varied kind of activities that avoid monotony and boredom, while helping to improve students' proficiency. It is task based as students learn through carrying out various communicative tasks.

Grammatical and communicative competences are two sides of the same coin. These two aspects of language work hand in glove to better content mastery and communication. It is not just about learning to communicate but also learning to communicate while using the language appropriately.

Grammar teaching and learning is both inductive and deductive. Here, it is not one way like in the Grammar Translation method where it was just deductive teaching of grammar and rules just presented to students nor the Direct Method which emphasised speech to the neglect of grammar rules. In this case, students also formulate the rules themselves and these help to develop their thinking abilities.

Notwithstanding the great improvements in this approach, it has a handicap in that it is time consuming and difficult to effectively implement in a context like Cameroon with large class sizes and other factors like multiple languages outside the classroom. Essossomo (2013 pp. 90-92) believes the application of CLT in Cameroon is not effective because of Examination/tests-oriented teaching, overcrowded classrooms, limited teaching hours (time constraints), the influence of background languages, lack of necessary resources and some social constraints like high familial, learners and school authorities' expectations for academic success. Most course instructors teach English under pressure from the school authorities. In the teaching activity, they should incorporate only aspects that can help students to better tackle questions in the official examinations with relative ease. Most teachers generally report that whenever they incorporate communicative activities in the teaching process, they are treated as "irresponsible". The product of these deficiencies was the fact that English language was taught more for the sake of acquiring certificate to the detriment of applying the knowledge for developing life skills for survival. Due to this, there was need to change orientation to embrace a model which emphasise Competency. This resulted to the birth of the Competence Based Approach (CBA) in Cameroon. According to J.C Bipoupout (2007), the CBA was prescribed to Cameroon following research work, global comparisons and the activities of the international organisations in support of responsive educational systems.

\subsection{Competency Based Approach}

The Competency Based Approach, also known as Competency Based Education (CBE), Competency Based Learning (CBL), Pedagogy of Integration, Performance Based Approach, Proficiency Based Approach, Mastery Based Approach and an Outcome Approach, began in USA in the 1970s, was introduced in the United kingdom in 1986 (Auerbach 1986:411-412) and was introduced in Cameroon in 2012. The application of its principles to language teaching is called competency-based language teaching (CBLT). It seeks to teach students the basic skills they need in order to prepare them for situations they commonly encounter in everyday life.

Jack C. Richards (2001) is of the opinion that there are two things to note about competency-based instruction. First, it seeks to build more accountability into education by describing what a course of instruction seeks to accomplish. 
Secondly, it shifts attention away from methodology or classroom processes, to learning outcomes. He says in a sense, one can say that with this approach it doesn't matter what methodology is employed what matters is the fact that it delivers the learning outcomes.

According to the glossary of educational reforms, CBA or CBL refers to systems of instruction, assessment, grading and academic reporting that are based on students demonstrating that they have learned the knowledge and skills expected of them as they progress through their education. Accordingly, the goal of CBA is to ensure that students are acquiring the knowledge that are deemed to be essential to success in school, higher education, careers and adult life and if students fail to meet up with expectations, they receive additional instruction, practice and academic support to help them achieve competency. The Glossary theories state that when schools implement CBA, it can entail significant changes in how the school operates, affecting the school's educational philosophy and culture to its methods of instruction, testing, grading, promotion and graduation.

CBA refers to teaching and learning that focuses on targeted competencies which are linked to the everyday needs of the learners. With CBA in connection to language teaching and learning, learners study language in situations and contexts that are varied and relevant e.g. applying for a job, shopping in a super market and making an offer. This is to ensure that learners develop linguistic competence and problem solving abilities that can be used in new and challenging situations in life. This gives meaning to students' learning and puts them at the centre of the teaching/learning transaction. It focuses on what learners are expected to do with language, the focal point being the outcomes of teaching. Here, we do not concentrate on the learners' knowledge of the language but on how they use it in real life situations to solve problems and get things done. According to Richards and Roger (2001) the learning activities are real world tasks and may be related to any domain of life.

The four basic language skills are taught in an integrated manner e.g. in teaching listening comprehension, the students' are being made to listen, read, write and speak. Emphasis is placed on the productive (speaking and writing), interpretive (reading and listening) and interactive competences (speaking and writing) while linguistic (grammar, vocabulary and pronunciation) and strategic competences are seen as supporting competences since they are just tools used to achieve an end. The focus is on learners being able to use English to accomplish tasks which are communicative in nature. This makes it closely linked to communicative language teaching.

\subsubsection{Components of CBA}

Weddel (2006), outlines CBA components as follows;

- Assessment of learners' needs: The teacher carries out a needs analysis to ascertain the competencies to be developed in learners.

- Selection of the competences: The teacher selects the competencies in accordance to the students' needs.

- Target instruction: Since in CBLT the aim is communicative competence in L2, the teacher selects instruction based on the communicative needs of the students.

- Evaluation of the competency attainment: The teacher evaluates the level of competency attainment in the students to see if it tallies with the stated outcomes. The process continues until competency is attained.

\subsubsection{Features of CBA}

According to Richards and Rogers (2001), the features of CBA are as follows;

- Competencies are stated in specific and measurable behavioural terms. Richards and Roger put it as outcomes that are made explicit a priori i.e. public knowledge known and agreed upon by the learners and teacher. Thus the students clearly know what behaviour and skills are expected of them.

- Contents are based on the learners' needs i.e. outcomes. A focus on life skills to be developed in learners. Here we have task or performance centred orientation where focus is on what the students can do with language and certain behaviours instead of knowledge of the language.

- The learners continue learning until mastery is demonstrated. Richards and Rogers (ibid) say assessment is based on the students' performance of specific behaviours instead of traditional paper and pen test.

- The instruction or teaching is paced to the needs of the learners. Richards and Rogers (ibid) state that instruction is individualised and student centred. Instruction is not time based but is centred on the progress of the individual students and at their own pace. This implies that, in CBA we hold learning bound and let time vary. 
- Nkwetisama (ibid) states that CBA provides learners with immediate feedback on assessment performance. Richards and Roger talk of continuous and on going assessment which implies that students are tested before teaching to determine the skills they lack and after teaching to evaluate their attainment of those skills.

- CBA centres on what learners need to learn; the application of basic skills in life language contexts. Richards and Rogers look at it from the point of successful functioning in society which means that language is taught in order to prepare the students for the different demands of the worlds.

- Modularised instruction in which the competences to be taught are systematically separated into manageable parts to ease mastery and progress by both teacher and students.

- Nkwetisama mentions extensive use of texts, media, and real life materials adapted to targeted competencies.

- He equally talks of unlimited variety of instructional techniques and group work.

\subsubsection{Teachers'/Students' Role in a CBA Framework}

In CBA, the teacher acts as a facilitator (facilitates learning), organiser (selects and arranges learning situation) and mentor (provides models and monitors students' learning) to create clear communicative objectives and provides communicative practices using English that supports learners in developing their skills and that focus on how students will speak, write, read or listen to interact, interpret, or produce in English language so as to communicate. Here, objectives should describe what learners will be able to do by a certain time and verbs used to describe this/these should describe something the teacher can see or hear. E.g. demonstrate, summarize etc. CBA tells the teacher what and how to teach. Also, the teacher provides feedback and individualised instruction, (Richards \& Rogers, ibid).

The students' role is to regularly practice the skills learnt in varied communicative situation and figure out the rules and patterns of language, then plan for and use strategies to help them learn and communicate. Learners are to be able to adapt and transfer knowledge from one setting to another.

\section{An Appraisal of the CBLT Model in Cameroonian Schools}

\subsection{Research Design, Sample and Sampling Techniques, Instruments for Data Collection}

This study made use of the survey research design. The purposive sampling technique was employed to select a sample of 100 English language teachers from 32 secondary schools in the North West and South West regions of Cameroon. (See the table below) Due the fact that this model was introduced in Cameroonian schools only in 2012, with instructions to start with the form one students only; this study only focussed in the junior secondary levels of forms one, two and three.

Table 1. Distribution of Teachers in Sample According to Type of School

\begin{tabular}{clcc}
\hline S/N & \multicolumn{1}{c}{ Name of school } & Type of school & Number of teachers selected \\
\hline 1. & G.B.H.S. Bamenda & Government & 03 \\
2. & G.B.H.S. Down Town Bamenda & Government & 03 \\
3. & G.H.S. Limbe & Government & 02 \\
4. & G.B.H.S. Bayelle Bamenda & Government & 03 \\
5. & C.C.A.S.T. Bambili & Government & 05 \\
6. & S.B.C. Limbe & Denominational & 03 \\
7. & S.H.C. Mankon & Denominational & 03 \\
8. & O.L.L.S.S. Bamenda & Denominational & 03 \\
9. & P.S.S. Mankon & Denominational & 02 \\
10. & S.J.C. Sasse Buea & Denominational & 03 \\
11. & P.C.H.S. Bamenda & Lay-private & 03 \\
12. & S.C. Nkwen & Lay-private & 03 \\
13. & N.C.H.S. Limbe & Lay-private & 03 \\
14. & G.B.H.S. Limbe & Government & 04 \\
15. & G.B.H.S. Santa & Government & 03 \\
16. & G.B.H.S. Mbeunkong & Government & 02 \\
\hline
\end{tabular}




\begin{tabular}{llll}
\hline 17. & G.B.H.S. Mbengwi & Government & 02 \\
18. & G.B.H.S. Mamfe & Government & 03 \\
19. & G.B.H.S. Kumba Station & Government & 03 \\
20. & C.C.A.S. Kumba & Government & 03 \\
21. & G.H.S. Babungo & Government & 01 \\
22. & G.H.S. Batoke & Government & 02 \\
23. & G.H.S. Mbonjo & Government & 03 \\
24. & G.H.S. Njikwa & Government & 02 \\
25. & G.H.S. Ekona & Government & 02 \\
26. & B.G.S. Molyko & Government & 03 \\
27. & P.H.S. Kumba & Denominational & 04 \\
28. & Bishop Rogan College Buea & Denominational & 04 \\
29. & B.H.S. Buea & Denominational & 04 \\
30. & Kulu M.C. Limbe & Lay-private & 03 \\
31. & C.C.C. Mankon & Lay-private & 03 \\
32. & N.H.C. Kumba & Lay-private & 01 \\
\hline
\end{tabular}

\subsection{Presentation and Analysis of Data}

\subsubsection{Presentation of Data from Questionnaire}

The data from the questionnaire shall be presented by means of tables and charts.

\subsubsection{Presentation of Data According to Academic Qualification of Respondents}

The questionnaires revealed the following distribution of responses relating to the level of academic attainment of the respondents.

Table 2. Distribution of Responses According to Academic Qualification of Respondents

\begin{tabular}{lcccccccc}
\hline \multirow{2}{*}{$\begin{array}{c}\text { Highest Academic } \\
\text { qualification }\end{array}$} & \multicolumn{9}{c}{ Type of school and number of teachers with specified academic } \\
& \multicolumn{9}{c}{ qualification } & & \multirow{2}{*}{ Total } \\
\cline { 2 - 7 } & \multicolumn{2}{c}{$\begin{array}{c}\text { Genominational } \\
\text { school }\end{array}$} & Lay-private school & & \\
\cline { 2 - 7 } & Number & $\%$ & Number & $\%$ & Number & $\%$ & Number & $\%$ \\
\hline G.C.E. A/L & 09 & $09.9 \%$ & 00 & $00.0 \%$ & 03 & $03.3 \%$ & 12 & $13.2 \%$ \\
First degree & 34 & $37.4 \%$ & 22 & $24.2 \%$ & 10 & $11.0 \%$ & 66 & $72.5 \%$ \\
Master degree & 06 & $06.6 \%$ & 03 & $03.3 \%$ & 03 & $03.3 \%$ & 12 & $13.2 \%$ \\
Others & 00 & $00.0 \%$ & 00 & $00.0 \%$ & 01 & $01.0 \%$ & 01 & $01.1 \%$ \\
Total & 49 & $53.7 \%$ & 25 & $27.5 \%$ & 17 & $17.6 \%$ & 91 & $100.0 \%$ \\
\hline
\end{tabular}

A close look at table 2 above leads to the conclusion that the respondents were dominated by first-degree holders, who constitute $72.5 \%$.

\subsubsection{Presentation of Data According to Level of Professional Training}

Data extracted from the questionnaires returned revealed the following distribution of responses relative to the level of professional training of the respondents. 
Table 3. Distribution of Responses According to the Level of Professional Training of Respondents

\begin{tabular}{|c|c|c|c|c|c|c|c|c|}
\hline \multirow{3}{*}{$\begin{array}{c}\text { Highest } \\
\text { Professional } \\
\text { qualification }\end{array}$} & \multicolumn{6}{|c|}{$\begin{array}{c}\text { Type of school and number of teachers with specified professional } \\
\text { qualification }\end{array}$} & \multirow{2}{*}{\multicolumn{2}{|c|}{ Total }} \\
\hline & \multicolumn{2}{|c|}{ Government school } & \multicolumn{2}{|c|}{$\begin{array}{l}\text { Denominational } \\
\text { school }\end{array}$} & \multicolumn{2}{|c|}{ Lay-private school } & & \\
\hline & Number & $\%$ & Number & $\%$ & Number & $\%$ & Number & $\%$ \\
\hline Grade 1 & 01 & $01.1 \%$ & 00 & $00 \%$ & 02 & $02.2 \%$ & 03 & $03.3 \%$ \\
\hline DIPES 1 & 18 & $19.8 \%$ & 09 & $09.9 \%$ & 08 & $08.8 \%$ & 35 & $38.5 \%$ \\
\hline DIPES II & 28 & $30.8 \%$ & 05 & $05.5 \%$ & 02 & $02.2 \%$ & 35 & $38.5 \%$ \\
\hline Others & 02 & $02.2 \%$ & 11 & $12.1 \%$ & 05 & $05.5 \%$ & 18 & $19.8 \%$ \\
\hline Total & 49 & $53.8 \%$ & 25 & $27.5 \%$ & 17 & $18.7 \%$ & 91 & $100 \%$ \\
\hline
\end{tabular}

The table above reveals that the respondents were dominated by DIPES I and DIPES II holders, who together constituted seventy out of the total number of respondents, in absolute terms (i.e. $78.9 \%$ of the respondents in relative terms). Seventy-three (i.e. $82.2 \%$ ) of the respondents were trained teachers (i.e. holders of DIPES I, DIPES II and Grade I certificates). Therefore, most of the respondents were trained teachers.

3.2.4 Presentation of Data According to Longevity in Teaching

Considering the duration of respondents in service in the training profession, the following data were obtained.

Table 4. Presentation of Data According to Longevity of Respondents in Teaching

\begin{tabular}{|c|c|c|c|c|c|c|c|c|}
\hline \multirow{3}{*}{$\begin{array}{c}\text { Number of years } \\
\text { of teaching }\end{array}$} & \multicolumn{6}{|c|}{ Type of school and number of teachers with specified longevity } & \multirow{2}{*}{\multicolumn{2}{|c|}{ Total }} \\
\hline & \multicolumn{2}{|c|}{ Government school } & \multicolumn{2}{|c|}{$\begin{array}{c}\text { Denominational } \\
\text { school }\end{array}$} & \multicolumn{2}{|c|}{ Lay-private school } & & \\
\hline & Number & $\%$ & Number & $\%$ & Number & $\%$ & Number & $\%$ \\
\hline$<10$ years & 21 & $23.1 \%$ & 07 & $07.7 \%$ & 07 & $07.7 \%$ & 35 & $38.5 \%$ \\
\hline $10-19$ years & 13 & $14.3 \%$ & 10 & $11.0 \%$ & 06 & $06.6 \%$ & 29 & $31.9 \%$ \\
\hline 20-30 years & 13 & $14.3 \%$ & 06 & $06.6 \%$ & 03 & $03.3 \%$ & 22 & $24.2 \%$ \\
\hline$>30$ years & 02 & $02.2 \%$ & 02 & $02.2 \%$ & 01 & $01.1 \%$ & 05 & $05.5 \%$ \\
\hline Total & 49 & $53.8 \%$ & 35 & $38.5 \%$ & 17 & $18.7 \%$ & 91 & $100.0 \%$ \\
\hline
\end{tabular}

The tables above show that 56 respondents in absolute terms (i.e. $61.5 \%$ in relative terms) had taught for at least 10 years. It can be safely concluded that the respondents were largely compose of experienced teachers.

\subsubsection{Presentation of Data According to Type of School}

The type of school: (i.e. government-managed school, denominational school or Lay-private school) was considered. The following data were obtained in this respect:

Table 5. Presentation of Data According to Type of School of Respondents

\begin{tabular}{lcccc}
\hline \multicolumn{1}{c}{ Type of school } & $\begin{array}{c}\text { Number of teachers } \\
\text { selected }\end{array}$ & \multicolumn{2}{c}{ Teachers that responded } \\
Number & $\%$ & $\begin{array}{c}\text { Relative return } \\
\text { rate }\end{array}$ \\
\hline State-managed & 55 & 49 & $53.9 \%$ & $92.7 \%$ \\
Denominational & 28 & 25 & $27.5 \%$ & $89.3 \%$ \\
Lay-private & 19 & 17 & $18.7 \%$ & $79.0 \%$ \\
Total & 100 & 91 & $100.0 \%$ & $91.0 \%$ \\
\hline
\end{tabular}

The table shows an overall return rate of $91.0 \%$, considered satisfactory for this study.

(i) Presentation of data relating to respondents' awareness about the C.B.A.

Table 6. Distribution of Responses Relating to Respondents' Awareness of the C.B.A

\begin{tabular}{ccccccc}
\hline \multicolumn{9}{c}{ Number of responses } & & \multicolumn{2}{c}{ Total } \\
\hline & Yes & \multicolumn{3}{c}{ No } & & \\
\hline Number & & $\%$ & Number & $\%$ & Number & $\%$ \\
\hline 85 & $93.4 \%$ & 06 & $06.6 \%$ & 91 & $100.0 \%$ \\
\hline
\end{tabular}


The data revealed that the majority of the respondents (93.4\%) were aware of the C.B.A. as a new approach adopted by the state of Cameroon, for implementation in the teaching/learning process.

(i) Presentation of data relating to respondents' knowledge and comprehension of what the C.B.A. entails

The table below shows the data collected in relation to respondents' knowledge and comprehension of what C.B.A. entails.

Table 7. Distribution of Responses Relating to Respondents' Knowledge and Comprehension of What the C.B.A. Entails

\begin{tabular}{|c|c|c|c|c|c|}
\hline \multicolumn{4}{|c|}{ Number of responses } & \multirow{2}{*}{\multicolumn{2}{|c|}{ Total }} \\
\hline & & & & & \\
\hline Number & $\%$ & Number & $\%$ & Number & $\%$ \\
\hline 16 & $17.6 \%$ & 75 & $82.4 \%$ & 91 & $100.0 \%$ \\
\hline
\end{tabular}

From the data, a large proportion (82.4\%) of respondents did not have an in-depth understanding of what the C.B.A actually entails.

(ii) Presentation of data relating to whether respondents have been trained on the application of the C.B.A. in the teaching and learning of the English language.

Table 8. Distribution of Responses Relating to Respondents' Training on the Use of the C.B.A.

\begin{tabular}{ccccccc}
\hline \multicolumn{3}{c}{ Number of responses } & & \multicolumn{2}{c}{ Total } \\
\cline { 1 - 4 } & Yes & \multicolumn{2}{c}{ No } & & Number & $\%$ \\
\hline Number & $\%$ & Number & $\%$ & & \\
\hline 52 & $57.1 \%$ & 39 & $42.9 \%$ & & 91 & $100.0 \%$ \\
\hline
\end{tabular}

From these statistics, it can be concluded that less than sixty percent of the respondents had received some formal training on the application of the C.B.A. in the teaching of the English language in secondary schools.

(iii) Presentation of data relating to whether the respondents had participated in any seminar or workshop dwelling on the application of the C.B.A.

Table 9. Distribution of Responses Relating to Participation in Seminars/Workshops on the Application of the C.B.A.

\begin{tabular}{|c|c|c|c|c|c|}
\hline \multicolumn{4}{|c|}{ Number of responses } & \multirow{2}{*}{\multicolumn{2}{|c|}{ Total }} \\
\hline & & & & & \\
\hline Number & $\%$ & Number & $\%$ & Number & $\%$ \\
\hline 77 & $84.6 \%$ & 14 & $15.4 \%$ & 91 & $100.0 \%$ \\
\hline
\end{tabular}

The data suggests that a large proportion $(84.6 \%)$ of the respondents had attended seminars/workshops on the application of the C.B.A. in the teaching and learning of the English language in secondary schools.

(iv) Presentation of data relating to the impression of the respondents about their readiness to implement the C.B.A.

Table 10. Distribution of Responses Relating to Readiness to Implement the C.B.A.

\begin{tabular}{lccccc}
\hline & \multicolumn{5}{c}{ Responses } \\
\cline { 2 - 6 } & $\begin{array}{c}\text { Ready to } \\
\text { implement }\end{array}$ & $\begin{array}{c}\text { Not ready to } \\
\text { implement }\end{array}$ & $\begin{array}{c}\text { Very demanding } \\
\text { to implement }\end{array}$ & $\begin{array}{c}\text { Challenging to } \\
\text { implement }\end{array}$ & Total \\
\hline $\begin{array}{l}\text { Number } \\
\text { Percentage }\end{array}$ & 29 & 15 & 30 & 39 & 113 \\
\hline
\end{tabular}

It was observed during the extraction of data from the questionnaires that most of those who considered the C.B.A. to be challenging and very demanding to implement did not indicate whether they were ready to implement it or not. This could be considered as an indirect indication that they were not ready to implement the C.B.A. 
On the strength of the last point above, it can be concluded that 84 of the responses (i.e. $74.3 \%$ ) showed that the respondents were not ready to implement the C.B.A. in the teaching and learning of the English language in secondary schools.

(v) Presentation of data relating to the confidence level of respondents in the implementation of the C.B.A.

Table 11. Distribution of Responses Relating to the Confidence Level of Respondent in the Implementation of the C.B.A.

\begin{tabular}{lcccc}
\hline & \multicolumn{4}{c}{ Responses } \\
\cline { 2 - 5 } & High & Average & Below average & Total \\
\hline Number & 16 & 61 & 14 & 91 \\
Percentage & $17.6 \%$ & $67.0 \%$ & $15.4 \%$ & $100.0 \%$ \\
\hline
\end{tabular}

It can be concluded that a large proportion of the respondents were not confident enough in their ability to implement the C.B.A. given that $82.4 \%$ of them had only up to average confidence in their ability to implement the C.B.A.

\section{PRESENTATION OF DATA COLLECTED ON THE EFFECTIVENESS OF THE IMPLEMENTATION OF THE CBA:}

i) Presentation of data relating to skills which respondents' teaching aimed at developing in learners

The table below shows data extracted from the questionnaire relating to the skills which respondents aimed at developing in their learners during their lessons.

Table 12. Distribution of Responses Relating to Skills Targeted for Development in Learners During Lessons

\begin{tabular}{lccccc}
\hline & \multicolumn{5}{c}{ Responses for various skills } \\
\cline { 2 - 6 } & Listening & Speaking & Reading & Writing & Total \\
\hline Number & 63 & 86 & 75 & 70 & 294 \\
Percentage & $21.4 \%$ & $29.3 \%$ & $25.6 \%$ & $23.8 \%$ & $100.0 \%$ \\
\hline A & &
\end{tabular}

A closer look at the data suggests that 252 (i.e. $85.7 \%$ ) of the responses indicated that all four skills were targeted in lessons delivered by respondents.

ii) Presentation of data relating to lesson preparation using the C.B.A.

Table 13. Distribution of Responses Relating to Lessons Preparation Using the C.B.A.

\begin{tabular}{lccc}
\hline & \multicolumn{3}{c}{ Responses } \\
\cline { 2 - 4 } & Yes & No & Total \\
\hline Number & 46 & 45 & 91 \\
Percentage & $50.6 \%$ & $49.4 \%$ & $100.0 \%$ \\
\hline
\end{tabular}

The data presented in table 13 suggests that slightly over $50 \%$ of the respondents had been preparing their lessons with the C.B.A. in focus.

iii) Presentation of data relating to real effectiveness of implementing of the C.B.A.

This table below shows data collected with respect to how effective respondents have been in the implementation of the C.B.A. in the teaching and learning of the English language in secondary schools.

Table 14. Distribution of Responses Relating to the Real Effectiveness of Implementation of the C.B.A.

\begin{tabular}{lcccccc}
\hline & \multicolumn{5}{c}{ Responses } \\
\cline { 2 - 7 } & $\begin{array}{c}\text { Very } \\
\text { effective }\end{array}$ & Fairly effective & $\begin{array}{c}\text { Averagely } \\
\text { effective }\end{array}$ & $\begin{array}{c}\text { Below } \\
\text { average }\end{array}$ & $\begin{array}{c}\text { Completely } \\
\text { ineffective }\end{array}$ & Total \\
\hline $\begin{array}{l}\text { Number } \\
\text { Percentage }\end{array}$ & 11 & 36 & 26 & 04 & 14 & 91 \\
\hline
\end{tabular}


A close look at table 14 reveals that $44(48.4 \%)$ of the respondents had at most an average level of effectiveness in the implementation of the C.B.A. in the teaching and learning of the English language in junior secondary schools. Furthermore, 47 of the respondents (i.e. 51.6\%) of the respondents were at least fairly effective in the implementation of the C.B.A.

iv) Presentation of data relating to the proportion of lessons incorporating the C.B.A.

Table 15. Distribution of Responses Relating to the Proportion of Lessons Incorporating the C.B.A.

\begin{tabular}{lccccc}
\hline & \multicolumn{5}{c}{ Responses } \\
\cline { 2 - 6 } & $100 \%$ & Above 50\% & Below 50\% & $0 \%$ & Total \\
\hline Number & 0.3 & 40 & 41 & 07 & 91 \\
Percentage & $3.3 \%$ & $44.0 \%$ & $45.0 \%$ & $07.7 \%$ & $100.0 \%$ \\
\hline
\end{tabular}

Table 15 leads to the deduction that 48 (i.e. $52.8 \%$ ) of the respondents had been incorporating the C.B.A. in less than $50 \%$ of their lessons. Furthermore, 43 (i.e. $47.2 \%$ ) had been incorporating the C.B.A. in less than $100 \%$ of their lessons.

\subsubsection{Presentation of Data Collected to Find Out Challenges Encountered in Implementing the CBA}

Data collected with respect to finding out whether teachers in the field were encountering significant difficulties in the implementation of the C.B.A. in the teaching and learning of the English language in junior secondary schools is presented in the table below:

Table 16. Presentation of Data Relating to Problems Encountered in the Implementation of the C.B.A.

\begin{tabular}{lcccccc}
\hline & \multicolumn{6}{c}{ Number of responses for various problems encountered } \\
\cline { 2 - 7 } & $\begin{array}{c}\text { Insufficient } \\
\text { instructional } \\
\text { resources }\end{array}$ & $\begin{array}{c}\text { Very large } \\
\text { class sizes }\end{array}$ & $\begin{array}{c}\text { Insufficient } \\
\text { motivation }\end{array}$ & $\begin{array}{c}\text { Inadequate } \\
\text { training }\end{array}$ & Others & Total \\
\cline { 2 - 7 } Number & 50 & 58 & 26 & 26 & 06 & 166 \\
Percentage & $30.1 \%$ & $34.9 \%$ & $15.7 \%$ & $15.7 \%$ & $03.6 \%$ & $100.0 \%$ \\
\hline
\end{tabular}

Remark: The other problems cited were: insufficient personnel and insufficient time allocation for lessons.

166 responses were obtained in this case and a close look at table 16 suggests that all the respondents faced significant difficulties in the implementation of the C.B.A. in the teaching of the English language in junior secondary schools. The difficulties identified were: insufficient instructional resources (30.1\%), very large class sizes $(34.9 \%)$, insufficient motivation (15.7\%), inadequate training (15.7\%) and insufficient time allocated for lesson $(03.6 \%)$.

3.2.7 Presentation of Data from Observation of Lessons in Some Schools:

The results of observing teachers in ten schools located in the North West and South West regions from the total number of schools employed (G.B.H.S. LIMBE, SBC. LIMBE G.B.H.S. Mbeunkong, C.C.A.S.T. Bambili, G.B.H.S. Bamenda, CCAS Kumba, GHS Mamfe, GHS Batoke, BGS Molyko) and included as presented in this section include:

- In most of the lessons observed, although the teacher used questioning techniques, class participation was very timid. A few students listened and spoke while the majority of them were busy discussing issues that were not related to the lessons.

- In the majority of the cases, the teacher did not relate the lesson to real-life situations in order to ease students' understanding.

- Most of the lessons were focused on listening and speaking. This might have been due to the large class size of at least 75 students, and the students' lack of textbooks, which contributed significantly to low class participation rate. 
- Another observation was the fact that most of the teachers still stuck to the old method of relying completely on the course book instead of /adapting the material in the textbook to teach through real-life situations.

- In many of the cases, the teacher guided the students at the introductory stage to come out with what was to be learned and when the students could not do so, the teacher ended up telling them everything.

- Emphasis was laid on the speaking skill to the detriment of the other skills.

- Most of the students were very passive in class, probably due to the very large class size, which made class control ineffective.

- In some cases, the teacher tried to implement the C.B.A. during the presentation stage of the lesson, through questioning techniques. The teacher asked many leading questions; students listened during much of the lesson and students' response was timid. Consequently, the teacher ended up doing much of the talking.

\section{Interviews}

A total of 39 English language teachers from the schools selected for this study were interviewed. The responses obtained from the teachers interviewed are summarized below:

- Most of them acknowledged that they were aware of the C.B.A. as a new approach in the educational system. However, they confessed that they had a shallow knowledge of what the C.B.A. entails. Consequently, they could not apply it effectively in their lessons.

- A large proportion (more than 75\%) of the interviewees confessed that they had not received any form of training on the application of the C.B.A. They indicated that they had attended a few seminars in which talks were presented on the C.B.A. However, no practical lesson was taught on the application of the C.B.A. in these seminars. Consequently, they were very reluctant to delve into something with which they were not familiar.

- Most of those who claimed that they were applying the C.B.A. did so unconsciously and for this reason, the best results could not be attained.

- In relation to language skills developed, most of those interviewed said that the C.B.A. was aimed at developing the speaking and reading skills, leaving out the listening and writing skills, which are equally important. Therefore, they were of the opinion that the C.B.A. is aimed at developing communicative competence only.

- The interviewees named a host of problems encountered in the implementation of the C.B.A., including the following:

Students were not willing to participate in the lessons; for this reason, in the course of helping students to understand using the questioning technique, the teacher ends up talking too much instead of the students doing more of the talking. This leads to another problem-that of insufficient time allocation for lessons.

It is time-consuming to prepare lessons using the C.B.A. because it needs the use of a lot of resources. They indicated that in teaching a lesson on a topic with which the students were unfamiliar, it became difficult to situate and do the teaching as well as paint a picture of the situation.

They also indicated that assembling teaching aids, especially given the very large class sizes, was very difficult. This made it near-impossible to teaching grammar lessons using the C.B.A., with the present state of affairs.

\section{Verification of Information from the Responses}

In this section, the responses provided in this study will be verified by considering the analysis of data collected using the questionnaire, observation and interviews.

\section{Verification on Whether Teachers in the Field Are Adequately Prepared to Carry Out the CBA}

The table below summarizes the analysis of data from the questionnaire relating to whether teachers are ready to implement the CBA 
Table 17. Summary of Data Analysis

\begin{tabular}{cccc}
\hline \multirow{2}{*}{$\begin{array}{c}\text { Item } \\
\text { number }\end{array}$} & Description of item's content in questionnaire & \multicolumn{2}{c}{ Percentage of responses } \\
\cline { 3 - 4 } & & $93.4 \%$ & $06.6 \%$ \\
2. & Awareness of C.B.A. & $17.6 \%$ & $82.4 \%$ \\
2. & Knowledge and comprehension of what C.B.A. entails & $57.1 \%$ & $42.9 \%$ \\
3. & Training on the application of the C.B.A. & $84.6 \%$ & $15.4 \%$ \\
4. & Seminars/workshops on the application of C.B.A. attended & $25.7 \%$ & $74.3 \%$ \\
5. & Readiness to implement C.B.A. & $17.6 \%$ & $82.4 \%$ \\
6. & Confidence in implementing C.B.A. & $49.3 \%$ & $50.6 \%$ \\
\hline
\end{tabular}

The chart below Fig 1 is a further display of the results:

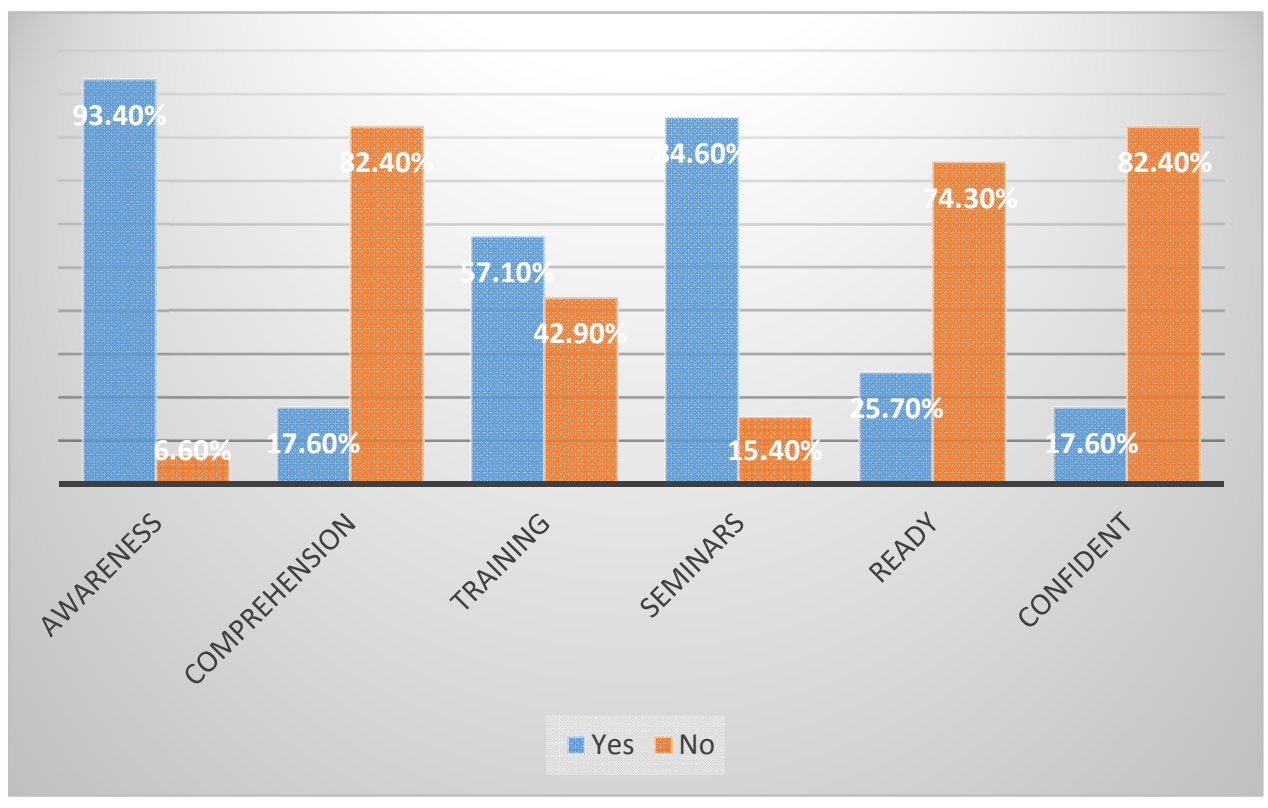

Figure 1. Chart Showing Summary of Data Analysed in Relation to Whether Teachers are Ready to Implement the CBA

- According to the analysis of data relating to whether teachers are ready to implement the CBA, obtained from the questionnaire (see tables 6 to 11 and figure 1 and the accompanying analysis), $49.3 \%$ of the respondents were adequately equipped and ready to implement the C.B.A. in the teaching and learning of English language in secondary schools, while $50.7 \%$ indicated that they were not adequately equipped and ready to implement the C.B.A.

- The information obtained through observation and interviews confirm the statistics above except that most of those interviewed (above 75\%) confessed that they had not received any formal training

- On the application of the C.B.A. in the teaching and learning of the English language in secondary schools. This was in sharp contrast to the information obtained from the questionnaire.

Summarily, the analysis presented above reveals that the proportion of respondents (less than 49.3\%), who are adequately equipped and ready to implement the C.B.A. in the teaching and learning of the English language in junior secondary schools is less than that for those who are not adequately equipped and ready to implement the C.B.A. (greater than 50.7\%). This means that the percentage of unfavourable responses (i.e. not equipped and not ready) is greater than the percentage of favourable responses (i.e. equipped and ready).

From inference, we conclude that teachers in the field are not adequately equipped and are not ready to implement the C.B.A. in teaching the English language to junior secondary school students in the North West and south West Regions of the Republic of Cameroon. 


\section{Verification of Whether the CBA is Being Effectively Implemented in the Teaching and Learning of English Language}

The table below summarizes the analysis of data from the questionnaire relating to the effectiveness of the implementation of the CBA in the teaching and learning of English Language:

Table 18. Summary of Data

\begin{tabular}{cccc}
\hline Item & Description of item's content in questionnaire & \multicolumn{2}{c}{ Percentage of responses } \\
\cline { 3 - 4 } number & & $85.7 \%$ & No \\
\hline 7. & All four skills developed in lessons taught & $50.6 \%$ & $49.3 \%$ \\
8. & Lessons prepared using C.B.A. & $12.1 \%$ & $87.9 \%$ \\
9. & Effective in applying C.B.A. in lessons & $47.3 \%$ & $52.7 \%$ \\
10. & C.B.A. applied in more than 50\% of lessons taught & $48.9 \%$ & $51.1 \%$ \\
\hline
\end{tabular}

The results above are further displayed on the chart below (figure 2), for better appreciation.

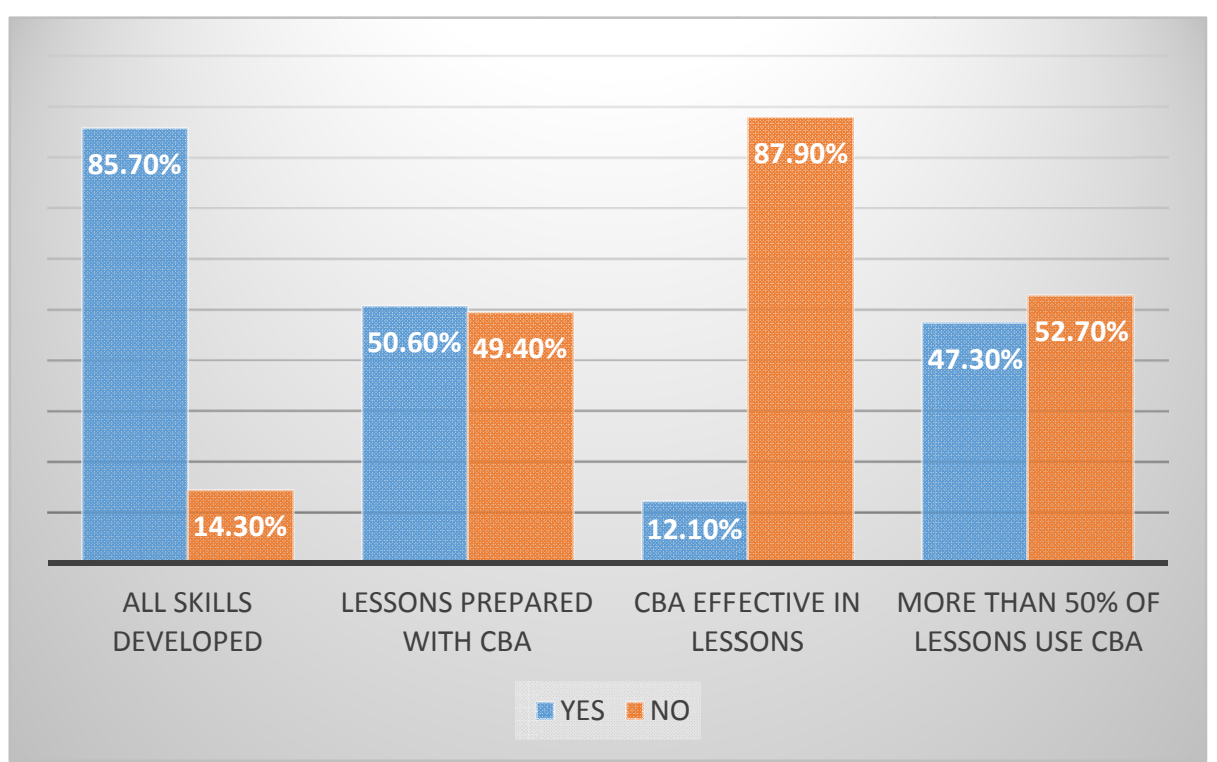

Figure 2. Chart Showing Percentages of Responses Relating to the Effectiveness in the Implementation of the CBA in the Teaching and Learning of English Language

According to the analysis of data relating to the effectiveness of the implementation of the CBA in the Teaching and learning of English Language, obtained from questionnaires (see table 12 to 18, figure 2 and the accompanying analysis), $48.9 \%$ of the respondents were effectively implementing the C.B.A. in the teaching and learning of the English language while $51.1 \%$ indicated that they were not effectively implementing the C.B.A. in the teaching and learning of the English language. The information obtained through observation and interviews confirmed the statistics above except that:

- Most of those observed and interviewed (about 72\%) confessed that their teaching focused more on the listening and speaking skills, with very little emphasis on the reading and writing skills, in disagreement with the information from the questionnaire;

- About $77 \%$ declared that they had not been preparing their lessons with a focus on the C.B.A., sharply contrasting the information obtained from the questionnaire;

- The proportion of respondents who incorporated the C.B.A. in at least $50 \%$ of their lessons was found to be about $29 \%$, much smaller than that obtained using the questionnaire (i.e. $47.3 \%$ ).

Summarily, the analysis presented above reveals that the proportion of respondents (less than $48.9 \%$ ), who are effectively implementing the C.B.A. in the teaching and learning of the English language is less than that for those who are not effectively implementing the C.B.A. (greater than 51.1\%). 
From inference, we conclude that teachers in the field encounter significant problems in the implementation of the C.B.A. in the teaching of the English language in junior secondary schools of the North West and South West Regions of the Republic of Cameroon.

\section{Findings}

\subsection{Discussion of Findings}

The analysis of data collected with respect to whether teachers in the field were adequately equipped and ready to implement the CBA leads to the conclusion that most teachers (at least 50.7\%) in the field are inadequately equipped and are not ready to implement the C.B.A. in the teaching and learning of the English language in junior secondary schools in the North West and South West Regions of the Republic of Cameroon.

Although the large majority (i.e. 84.6\%) of the respondents had attended seminars/workshops on the application of the C.B.A. in the teaching and learning of the English language, most (i.e. 82.4\%) of them did not understand what the C.B.A. entails. $57.1 \%$ of the respondents from the questionnaire claimed that they had been trained on the application of the C.B.A. However, from interviews conducted with the respondents, it was unfortunate to find that the large majority (about $75 \%$ ) of them confessed that they did not think they had received sufficient training to enable them implement the C.B.A. in English language teaching and learning. From interviews conducted with some of the teachers, most of them indicated that much of the work done during the seminars which they had attended was very theoretical, since no practical lessons were taught to demonstrate the application of the C.B.A. in the teaching and learning of the English language. $74.3 \%$ of the respondents declared that they were not confident enough in their ability to implement the C.B.A. and consequently, they were not ready to embrace this paradigm shift in English language teaching and learning, as confirmed by $82.4 \%$ of the respondents.

4.1.1 Discussion of Findings for Whether the CBA is Being Effectively Implemented in Teaching and Learning of the English Language

The analysis of data collected through the questionnaire, observation and interviews, with respect to the above subject leads to the conclusion that the C.B.A. is not being effectively implemented in the teaching and learning of the English language in junior secondary schools in the North West and South West Regions of the Republic of Cameroon.

From the questionnaire, although about $50.6 \%$ of the teachers claimed that they prepared their lessons with C.B.A. in focus, only $47.3 \%$ indicated that they incorporated the C.B.A. in at least half of their lessons.

Data analysed from the questionnaires showed that $85.7 \%$ of the respondents claimed that they aimed at developing all four language skills (listening, speaking, reading and writing) in their teaching. However, most of those observed and interviewed (about $72 \%$ ) confessed that their teaching focused more on the listening and speaking skills, with very little emphasis on the reading and writing skills, in disagreement with the information from the questionnaires. Moreover, about $77 \%$ of the respondents indicated that they had not been preparing their lessons with a focus on the C.B.A., again sharply contrasting the information obtained from the questionnaire. In addition, the proportion of respondents who incorporated the C.B.A. in at least $50 \%$ of their lessons was found to be about $29 \%$, much smaller than that obtained using the questionnaires (i.e. $47.3 \%$ ).

Finally, it was found out that only $12.09 \%$ of the respondents indicated that they were effectively implementing the C.B.A. in English language teaching and learning in secondary school, while the large majority (87.9\%) shared the opinion that they were ineffective, as far as the implementation of the C.B.A. in English language teaching and learning is concerned.

4.1.2 Discussion of Findings of Whether Teachers in the Field Encounter Significant Difficulties in Implementing the CBA

From the analysis of data collected in relation to the above subject, it was found that all the teachers in the field shared the opinion that they faced significant difficulties in the implementation of the C.B.A. in the Republic of Cameroon. The following problems were identified to be particularly serious: inadequate instructional resources (indicated by $30.1 \%$ of the responses); lack of adequate training (indicated by $15.7 \%$ of the responses); very large class sizes (revealed in $34.9 \%$ of the responses); insufficient motivation (shared by $15.7 \%$ of the responses) and others, such as insufficient time allocated for English language lessons (indicated by $03.6 \%$ of the responses).

Summarily, it can be deducted from the discussion above that teachers in the field are not adequately equipped and are not yet ready to implement the C.B.A. in English language teaching and learning due to a number of difficulties. 
Consequently, the C.B.A. is not being effectively implemented in the teaching and learning of the English language in junior secondary in the North West and South West Regions of the Republic of Cameroon.

\subsection{Pedagogic Relevance of the Study}

This study is very significant as far as pedagogy is concerned. The state of Cameroon has adopted the C.B.A. as the approach that should be used in all secondary schools in the country. This study provides the authorities in the Ministry of Secondary Education with information about the situation in the field, as far as the implementation of the C.B.A. in concerned. Through this study, they would know that the training of teachers in the field as well as their equipment, is inadequate and consequently they cannot implement the C.B.A. in the teaching and learning of the English language in secondary schools considering the present state of affairs.

\section{Recommendations}

In view of the findings of this study, recommendations shall be made to the following group of people:

\subsection{Authorities in the Ministry of Secondary Education in Yaoundé}

This ministry is responsible for restructuring the school curriculum, so as to incorporate the C.B.A. as well as ensuring that the C.B.A. is effectively implemented in the teaching/learning process in secondary schools. Unfortunately, the prevailing situation suggest that "the cart has been put before the horse", in the sense that teachers in the field are expected to implement the C.B.A. whereas they have not been prepared for this assignment by way of adequate training and equipment with the necessary instructional resources.

These authorities should know that teachers already in service in the field need to be trained and equipped in order to make them fit and confident in implementing the C.B.A. in the teaching-learning process. They should therefore identify countries in which the C.B.A. has been implemented successfully and learn from the experts the strategies employed. Then they could borrow the knowledge which would be transmitted to other teachers at home. In this way, all teachers in the field would eventually be well trained and amply equipped to implement the C.B.A. in the teaching and learning of the English language in secondary schools in Cameroon.

The implementation of the C.B.A. is very challenging and very demanding too. Consequently, the Ministry of Secondary Education should do all in their power, to improve on the working conditions of teachers, so that they would be motivated to do their work well, including the implementation of the C.B.A. in the teaching/learning process.

\subsection{Authorities of the Higher Teacher Training Colleges}

They should redesign their training programmes to incorporate the C.B.A. In this way, trainees who graduate from these institutions in charge of teacher training would be grounded in the application of the C.B.A. in the teaching/learning process, by the end of their training. Once in the field, they would go ahead to implement the C.B.A. in their teaching effectively.

Considering the fact that a good number of secondary schools in the North West and South West Regions in particular and Cameroon in general do not have sufficient number of English language teachers, the authorities of the Higher Teacher Training Colleges should do everything possible to convince the Government to increase the intake of students into their institutions, especially in the departments of English Modern Letters.

Finally, there are indications that most of the students who are recruited to be trained in the department of English modern letters end up specializing in teaching literature in English. In order to solve this problem, a separate department should be created for English language alone, so that all students trained in this department would teach the English language upon graduation.

\subsection{Regional Pedagogic Inspectors}

They should organize in-service training seminars on a regular basis, on the C.B.A. and its application in the teaching/learning process. These seminars should be decentralized so that they take place at regional, divisional and sub-divisional levels. In this way, all teachers in the field would be involved in the in-service training programmes. Moreover, during such seminars, concrete lessons showing how the C.B.A. should be applied in the teaching/learning process should be taught to participants, by experts in this domain. In this way, the effective implementation of the C.B.A. in the teaching of the English language in secondary schools would be guaranteed.

\subsection{Principals of Secondary Schools}

One of the problems hampering the implementation of the C.B.A. in the teaching of the English language in junior 
secondary schools lies in the fact that many of the classes are very large, in terms of the number of students. There are cases in which a teacher has to teach four or five streams of students, each numbering at least eighty. Clearly, the implementation of the C.B.A. in this case is near-impossible.

In order to solve this problem, principals of secondary schools should respect the Ministerial prescription of sixty students per class, so as to avoid overcrowding and reduce the students-teacher ratio to a manageable level. This would improve a student-teacher interaction, give more room for feedback to be given to students and make the teacher's role as a facilitator in the C.B.A. more practicable.

\subsection{Parents of Learners}

In order for students to benefit from the C.B.A., they must be ready to do research on their own, with the teacher playing the role of facilitator, organizer, prompter, controller, counsellor, adviser, director and supervisor. This obviously implies that the learner has a very important role to play and places demands in the domains of books and other resources necessary for individual student research. Parents are therefore called upon to provide the resources which their children need, so that they can benefit fully from the C.B.A.

\section{Conclusion}

From this study it is important to reiterate the fact that there is no single model which could be looked upon as the one ideal model to be employed for the teaching and learning of English language. As demonstrated from findings in this study and according to Ur (1996) 'no single method is optimally effective for teaching languages.' It seems we have learned enough from past experiences and research so as to practice a cautious eclecticism or integrated approach, where, as Swan (1985b:87) puts it we both try out new techniques and hold on the useful older ones. We have come to realize, in Stern's (1983:474) words, that 'language teaching cannot be satisfactorily conceptualized in terms of teaching method alone.' And a majority of language specialists consider eclecticism a legitimate solution to the lack of universal solutions offered by any single method or, as Rodgers (2001:4) terms it, 'method synergistics' or a 'disciplined eclecticism'. Thus it could be concluded that it is impossible to arrive at the perfect approach or a technique for language learning in any context. Language learning is such a complex process that it is impossible to offer a single solution to all our problems. Perhaps the best method is the one which works, and this varies from context to context. Any method which creates conditions for learning to take place is good. It should enable the learner to acquire the strategies of learning rather than merely equipping him with knowledge. What is important for the teacher, therefore, is to find out what approach and what method will enable him/her to realize a particular objective under a set of particular circumstances.

\section{References}

Allen, H. B. (1989). Teaching English as a second Language. New Delhi, Sterling Publication.

Auerbach, E. R. (1986). TESOL Competence-Based ESL: One Step Forward or Two Steps Back? TESOL Quarterly. California, San Jose State University.

Bhatia, K., \& Bhatia, B. D. (1972). The Principles and Methods of Teaching. Delhi: Doaba House Publishers.

Bipoupout, J. C. (2007). Curriculum change and competency based approaches: A Worldwide Perspective. Prospects: quarterly review of comparative education, 37(2), 205-221.

Broughton, G. (1980). Teaching English as a Second/Foreign Language. New York: Rutledge

Brown, H. Douglas (2001). Teaching by Principles: An Interactive Approach to Language Pedagogy. Longman/Pearson Education. New York, White Plains.

Cameroon (1995). Ministry of Education, National meeting on Education general report, Yaoundé.

Cameroon (1998). Law No. 98/004 of $14^{\text {th }}$ April 1998 to Lay Down Guidelines for Education in Cameroon. Yaoundé, Ministry of National Education.

Castling, A. (1996). Competence-Based Teaching and Learning. London: Macmillan.

Chomsky, N. (1965). Aspects of the Theory of Syntax. Cambridge. Massachusetts: MIT Press.

Cohen, A. (1980). Testing Language Ability in the Classroom. Rowley: Newbury House Publishers, Inc.

CRISES (2005). Strategies and Styles of Learning. TESOL quarterly, California.

Crystal, D. (1987). The Cambridge Encyclopaedia of Language. London: Cambridge University Press. 
Crystal, D. (1997). English as a Global Language. England: Cambridge University Press.

Diller, K. C. (2004). 'The Language Teaching Controversy', quoted in Diane-Larsen-Freeman "Techniques and Principles in Language Teaching”. London: Oxford University Press.

Essossomo, S.M. (2013). The Teaching of English to French Speaking Cameroonian Learners: A Phonological Appraisal. Germany, LAP Lambert Academy Publishers.

Hill, J., \& Houghton, P. (2001). A Reflection on Competency-based Education: Comments from Europe. Journal of Management Education, 25(2), 146-166. http://dx.doi.org/10.1177/105256290102500204

Hughes, L. G. (1948). Learning and Teaching: An Introduction to Psychology and Learning. London, Longman.

Hymes, S. (1972). Towards Communicative Competence. Philadelphia: Pennsylvania University Press.

Kumaravadivelu, B. (2003). Beyond Methods: Macrol-Strategies for Language Teaching. New Haven and London: Yale University Press.

Kumaravadivelu, B. (2006). Understanding Language Teaching: From Method to Post-Method. London: Laurence Erlbaum Associates.

Mackay, W. F. (1977). Language Teaching Analysis in Teaching English in India Today (ed.). By Yardi, V.V. New York, Mouton.

Njwe, E. (2014). Introductory Phonetics, English Speech and Usage. Germany, LAP LAMBERT Academic Publishing.

Richard, J. C., \& Rodgers, T. (2001). Approaches and Methods in Language Teaching (2 ${ }^{\text {nd }}$ edition). Cambridge, England: Cambridge University Press. http://dx.doi.org/10.1017/CBO9780511667305

Richards J. C. (2001). Curriculum Development in Language Teaching. UK: Cambridge University Press. http://dx.doi.org/10.1017/cbo9780511667220

Salla, M.B. (2011). Beyond Grammar. Yaounde, Horizon Books.

Serdenciuc, N. L. (2013). Competency-Based Education- Implications on Teachers' Training. Procedia Social and Behavioural Sciences, 76, 754-758. http://dx.doi.org/10.1016/j.sbspro.2013.04.200

Stern, H.H. (1983). Fundamental Concept of Language Teaching. Oxford: OUP.

Swan, M. (1985). A Critical Look at the Communicative Approach. ELT Journal, 39(1 and 2), 24-96.

Tanda, V.A., \& Mumambang, C.A. (2006). The Influence of Globalization on the Standards of English Used in Cameroon. In Chia, E., Tala, K.I and Tanda, V.A. (Eds.), Perspectives on Language Study and Literature in Cameroon. Limbe: ANUCAM.

Ur, P. (1996). A Course in Language Teaching: Practice and Theory. In Williams, M. and Wright T. (Eds.), Cambridge Teacher Training and Development. Cambridge University Press.

Verghese, C.P. (1989). Teaching English as a Second Language. Delhil: Sterling Publishers. 